\title{
Performance and carcass traits of goat kids fed high-concentrate diets containing citrus pulp or soybean hulls
}

\author{
Desempenho e características da carcaça de caprinos alimentados com dietas de alto teor de \\ concentrado, contendo polpa cítrica ou casca de soja
}

\begin{abstract}
Daniel Montanher Polizel ${ }^{\mathrm{I}}$ Luiz Guilherme Mezzena Gobato ${ }^{\mathrm{I}}$ Rodrigo Araújo de Souza $^{\mathrm{I}}$ Renato Shinkai Gentil ${ }^{I}$ Evandro Maia Ferreira ${ }^{I}$ Ana Paula Alves Freire ${ }^{I}$ Ivanete Susin ${ }^{I^{*}}$
\end{abstract}

\section{ABSTRACT}

The objective in this trial was to determine the effects of partial replacement of ground corn by citrus pulp or soybean hulls on performance and carcass characteristics of feedlot goat kids. Twenty one Boer x Saanen kids (initial BW $15.8 \pm 0.7 \mathrm{~kg}$ ), nine males and 12 females, were distributed in a complete randomized block design, according to sex and initial body weight Treatments were set by replacing 50\% of ground corn (DM basis) for citrus pulp or soybean hulls; whereas, forage concentrate ratio was of 10:90. Partial replacement of corn by citrus pulp or soybean hulls increased dry matter intake, average daily gain and final body weight, but feed efficiency was not affected. There was no difference between citrus pulp or soybean hulls. Inclusion of coproducts increased slaughter weight, hot and cold carcass weight and longissimus muscle area, with no difference between citrus pulp and soybean hulls. Subcutaneous fat thickness, hot and cold carcass yields, shrink after chilling and body wall thickness were not affected by treatments. Citrus pulp and soybean hulls can replace 50\% of ground corn (DM basis) increasing dry matter intake and weight gain in goat kids enabling higher slaughter weight at earlier age.

Key words: coproducts, feedlot, goats

\section{RESUMO}

O objetivo neste estudo foi avaliar a substituição parcial do milho pela polpa citrica (PC) ou casca de soja (CS) sobre o desempenho e as características de carcaça de cabritos confinados. Foram utilizados 21 cabritos Boer x Saanen (PC inicial de $15,8 \pm 0,7 \mathrm{~kg}$ ), sendo nove machos e 12 fêmeas, distribuídos em delineamento experimental de blocos completos casualizados (7 blocos e 3 tratamentos). Os tratamentos foram definidos pela substituição de $50 \%$ do milho pela PC ou CS (\% da MS). As dietas continham $90 \%$ de concentrado e $10 \%$ de volumoso. A substituição parcial do milho pela $P C$ ou CS aumentou o consumo de matéria seca (CMS), o ganho médio diário de peso corporal (GMD) e o peso corporal final, porém a eficiência alimentar não foi alterada. A inclusão dos coprodutos aumentou o peso corporal ao abate (PCA), o peso de carcaça quente (PCQ) e fria (PCF) e a área de olho de lombo (AOL). Não houve diferença entre os coprodutos com relação ao desempenho e às características de carcaça. A substituição de $50 \%$ do milho $(64,2 \%$ de MS) pela polpa citrica ou casca de soja, em dietas com alto concentrado, aumenta o consumo de matéria seca e o ganho médio diário de peso dos cabritos, possibilitando maior peso ao abate com idade menor.

Palavras-chave: coprodutos, confinamento, caprinos.

\section{INTRODUCTION}

Goat meat has gained market mainly due to increased demand for healthy foods because of its low fat content. However, in many regions, the seasonality in the production of roughage and the low quality of pastures hinder the termination and the slaughter of grazing animals in an early age. One of the possible strategies to accelerate the growth of animals is confinement.

The price of ingredients used in feedlot diets tend to be influenced mainly by supply and demand. Thus, in order to reduce food spending and not compete with human consumption, the use of agro-industrial coproducts may be a reliable strategy to replace corn.

Soybean hulls (SH) are a coproduct from soybean processing. From each ton of processed soybean, approximately $2 \% \mathrm{SH}$ is generated. Soybean

\footnotetext{
'Departamento de Zootecnia, Escola Superior de Agricultura "Luiz de Queiroz" (ESALQ), Universidade de São Paulo (USP), Av. Pádua Dias, 11, 13418-900, Piracicaba, SP, Brasil. E-mail: ivasusin@usp.br. *Corresponding author. 
hulls are characterized by high NDF (NRC, 2007) and low lignin content (ANDERSON et al., 1988; MULLIGAN et al., 1999). Also it is practically free of starch (HSU et al., 1987), which reduces the risk of ruminal acidosis in animals fed with diets containing high levels of concentrate (FERREIRA et al., 2011b).

The pelleted citrus pulp (CP) features low NDF content, $21.0 \%$ in the dry matter (DM), however it has a high concentration of pectin, $22.3 \%$ in the DM (NRC, 2007) and can be used as an energy ingredient (BAMPIDIS \& ROBINSON, 2006). The pectin present in $\mathrm{CP}$ is a complex carbohydrate with high and rapid rumen degradation (VAN SOEST et al., 1991) and when added to the diet of ruminants, it stimulates the production of acetic acid rather than lactic acid, elevating the ruminal pH (WING et al., 1988).

There are few studies on the use of $\mathrm{SH}$ and $\mathrm{CP}$ in diets of early weaned goat kids. The objective in this study was to determine the effects of replacing $50 \%$ of corn for $\mathrm{SH}$ or $\mathrm{CP}$, in $90 \%$ concentrate diets, on growth and carcass characteristics of early weaned goat kids.

\section{MATERIALS AND METHODS}

The trial was conducted at the Sheep and Goats Intensive Production System (SIPOC) of the Department of Animal Science of the "Luiz de Queiroz" College of Agriculture (ESALQ), University of São Paulo, in Piracicaba, state of São Paulo, Brazil. All procedures involving animals were approved by the Ethics Committee on Animal Use in Research (CEUAP) of the ESALQ.

Twenty-one Boer x Saanen goat kids were used, nine males and 12 females, with an average initial weight of $15.8 \pm 0.7 \mathrm{~kg}$ and $80 \pm 1.3$ days of age. Animals were kept indoors, in individual tie-stalls, with a slatted floor and provided with feed bunks and water cups.

The experimental design was a randomized complete block design with three treatments and seven replications, and the animals were blocked by sex, age and initial weight. The experiment lasted 56 days and was divided into two periods of 28 days. Diets were isonitrogenous ( $16.4 \pm 0.3 \%$ crude protein) consisting of $10 \%$ roughage (coastcross hay) and $90 \%$ concentrate (DM basis) and formulated as recommended by NRC (2007). Half of the dry matter content of corn in the control diet (CT) was replaced by citrus pulp (CP) or soybean hulls ( $\mathrm{SH}$ ), corresponding to the $\mathrm{CP}$ and $\mathrm{SH}$ diets, respectively (Table 1).

Feed ingredients (corn, citrus pulp, soybean hulls and hay) were grounded using a mill (Nogueira ${ }^{\circledR}$
Table 1 - Ingredients and chemical composition of the experimental diets (DM basis).

\begin{tabular}{llll}
\hline & & & \\
Item & CT & CP & SH \\
\hline Ingredients & & & \\
Coastcross hay & 10.0 & 10.0 & 10.0 \\
Soybean meal & 16.5 & 17.6 & 13.3 \\
Ground corn & 64.2 & 32.1 & 32.1 \\
Citrus pulp & - & 32.1 & - \\
Soybean hulls & - & - & 32.2 \\
Wheat bran & 5.0 & 5.7 & 8.2 \\
Limestone & 1.8 & 0.0 & 1.7 \\
Mineral mix & \\
Ammonium chloride & 2.0 & 2.0 & 2.0 \\
Chemical composition & 0.5 & 0.5 & 0.5 \\
Dry matter & & & \\
Crude protein & 90.2 & 92.5 & 91.0 \\
Neutral detergent fiber (NDF) & 21.2 & 26.1 & 38.7 \\
Organic matter & 93.6 & 92.7 & 93.0 \\
Mineral matter & 6.4 & 7.3 & 7.0 \\
\hline
\end{tabular}

${ }^{1} \mathrm{CT}$ : Control diet, with $64.2 \%$ corn; CP: citrus pulp diet, replacement of $50 \%$ of corn by $\mathrm{CP}$; SH: Soybean hulls diet, replacement of $50 \%$ of corn by $\mathrm{SH}$.

${ }^{2}$ Composition: Ca: $13.4 \%$, P: $7.5 \%$, Mg: $1 \%$, S: $7 \%$, Cl: $21.8 \%$, $\mathrm{Na}: 14.5 \%$, Mn: $1100 \mathrm{mg} \mathrm{kg}^{-1}$, Fe: $500 \mathrm{mg} \mathrm{kg}^{-1}$, Zn: $4600 \mathrm{mg} \mathrm{kg}^{-1}$, $\mathrm{Cu}: 300 \mathrm{mg} \mathrm{kg}^{-1}$, Co: $40 \mathrm{mg} \mathrm{kg}^{-1}$, I: $55 \mathrm{mg} \mathrm{kg}^{-1}$, Se: $30 \mathrm{mg} \mathrm{kg}^{-1}$.

DPM-4, Itapira, Brazil) fitted with a screen of $10 \mathrm{~mm}$ sieve. Later, they were mixed with other ingredients (soybean meal, wheat bran, limestone, mineral salt and ammonium chloride) with the aid of a horizontal mixer $\left(\right.$ Lucato $^{\circledR}$, Limeira, Brazil) with capacity of $500 \mathrm{~kg}$. In all experimental diets, $25 \mathrm{mg}$ of sodium monensin was added per $\mathrm{kg}$ of feed.

Ration was weighed daily on an electronic scale accurate to $1 \mathrm{~g}$ (Marte ${ }^{\circledR}$, LC 10, Sao Paulo, Brazil) and was offered ad libitum to animals. Amounts of feed given to animals were calculated according to previous DMI, and adjustments were made when needed, so that refused feed did not exceed $10 \%$ of daily intake. Orts were recorded weekly to determine DMI. A sample was taken from offered feed and orts of each experimental unit once a week. Orts samples were composed per treatment and kept at $-18^{\circ} \mathrm{C}$ for later analysis.

Samples of offered feed and orts were processed in a Wiley type mill, fitted with screens with $1 \mathrm{~mm}$ sieves. The determination of dry matter (DM), mineral matter (MM) and crude protein (CP) was performed according to AOAC (1990). The fiber insoluble in neutral detergent (NDF) was determined using heat-stable $\alpha$-amylase and sodium sulfite, according to VAN SOEST et al. (1991). The 
organic matter $(\mathrm{OM})$ was calculated by difference between DM and MM. The analyses were performed at the Laboratory of Food Science and Laboratory of Animal Nutrition and Reproduction, Department of Animal Science at ESALQ/USP.

Animals were weighed after a solid fasting period of 14 hours at the beginning of the experiment and at the end of each period. Using these weights and DMI, average daily gain (ADG) and feed efficiency (FE) were calculated. At the end of the 56-d feeding trial, after fasting for 14 hours, animals were weighed and slaughtered in a commercial abattoir. After slaughter the hot carcass weight (HCW) and yield (HCY) were calculated. After 24 hours in cold storage at $4^{\circ} \mathrm{C}$, the chilled carcass weight $(\mathrm{CCW})$ and yield (CCY) were recorded. Also the shrink after chilling was determined. After weighing, carcasses were ribbed between the $12^{\text {th }}$ and $13^{\text {th }}$ thoracic vertebra and the subcutaneous back fat thickness (SF), LM area (LMA) and body wall thickness (BWT) were determined. The SF and the BWT were determined using a digital caliper graduated in millimeters. Body wall thickness was measured $12.5 \mathrm{~cm}$ laterally from the midline of the spine (NOTTER et al., 2004). For the determination of LMA, the exposed Longissimus dorsi muscle area was traced on acetate paper, and the area was determined by using a planimeter graduated in square centimeters.

Statistical analyses were performed using the MIXED procedure from SAS (2008). All data was subject to the Shapiro-Wilk test to verify the normality of residue and removal of outliers, the homogeneity of variances was also checked using the Levene test. The data set that did not respect those premises was subjected to logarithmic, inverse or square root transformation.

The ADG, DMI and FE variables were analyzed as repeated measures over time, using the following model: $\mathrm{Yijk}=\mu+\mathrm{Bi}+\mathrm{Tj}+\mathrm{Eij}+\mathrm{Pk}+(\mathrm{BP})$ $\mathrm{ik}+(\mathrm{TP}) \mathrm{jk}+$ Eijk, where $\mu=$ overall mean; $\mathrm{Bi}=$ block effect ( $\mathrm{i}=1$ to 7$) ; \mathrm{Tj}=$ treatment effect $(\mathrm{j}=1$ to 3$) ; \mathrm{Eij}=$ residual error $\mathrm{A} ; \mathrm{Pk}=$ experimental period effect $(\mathrm{k}=1$ to 2); (BP) ik = interaction block $\mathrm{x}$ trial period; (TP) $\mathrm{jk}=$ interaction treatment $\mathrm{x}$ trial period, and Eijk = residual error B. Block and interaction block x period were included as random effects. Nine covariance matrices were tested and defined according to the lowest value obtained for "Akaike's Information Criterion" (AIC). The means of the treatments were obtained by LSMEANS command. The data sets were evaluated by orthogonal contrasts, being rated the control treatment versus $\mathrm{CP}$ and $\mathrm{SH}$, as well as the CP versus SH. The effects of period and the interaction diet versus period were defined by the $\mathrm{F}$ test of the variance analysis.

For the animal weights and the carcass characteristics, the model used was: Yij $=\mu+\mathrm{Bi}$ $+\mathrm{Tj}+$ Eij, where $\mu=$ overall mean; $\mathrm{Bi}=$ block effect ( $\mathrm{i}=1$ to 7$) ; \mathrm{Tj}=$ treatment effect $(\mathrm{j}=1$ to 3 ), and Eij $=$ residual error. Block was included as a random effect. The treatment means were obtained by LSMEANS command. The data sets were analyzed by orthogonal contrasts same as the ones mentioned above. All analyzed variables were considered as significant effects when $\mathrm{P} \leq 0.05$.

\section{RESULTS AND DISCUSSION}

The partial replacement of corn by $\mathrm{CP}$ or $\mathrm{SH}$ resulted in increased DMI $(\mathrm{P}<0.01)$. However, there was no difference between $\mathrm{CP}$ and $\mathrm{SH}$ diets (Table 2). The ADG was also higher $(\mathrm{P}=0.02)$ for the diets containing the coproducts compared to the control, with no difference between the $\mathrm{CP}$ and $\mathrm{SH}$ diets. Feed efficiency was not affected by diets. Thus, the higher ADG of the animals receiving the coproducts can be justified by the greater DMI. These results indicate that, despite the high NDF content of SH, it did not promote physical limitation to the consumption, which must be attributed to its high ruminal digestibility (IPHARRAGUERRE \& CLARK, 2003), high rate of passage through the rumen due to its small particle size (MERTENS, 1997) and high specific gravity (BHATTI \& FIRKINS, 1995). Additionally, the fact that the inclusion of SH (FERREIRA et al., 2011a) or CP (WING et al., 1988) in diets with high concentrate maintains rumen $\mathrm{pH}$ higher and stable throughout the day may have contributed to the increase in the DMI and consequently higher ADG of the animals receiving the coproducts. FERREIRA et al. (2011a) also observed a linear increase in the DMI in response to the replacement of up to $45 \%$ of the corn of lamb's diet by $\mathrm{SH}$ without effects on ADG. The authors justified that this increase in DMI occurred to compensate reduction in dietary energy concentration as $\mathrm{SH}$ was included in the diets. According to NRC (2007), the energy concentration in corn is higher than in $\mathrm{SH}$ (3.9 and 3.4Mcal of $\mathrm{ME} \mathrm{kg}^{-1}$ of DM, respectively).

In this experiment, the increased DMI in the second period was already expected due to the increased weight of animals. However, there was an interaction between diet and time for DMI $(\mathrm{P}=0.05)$. After analyzing the interaction between diet and period (Figure 1), it was noted that for all diets there was an increase in the DMI from the first to the second period, but this increase was more pronounced for animals in the $\mathrm{CP}$ and $\mathrm{SH}$ diets. This effect on the DMI of the 
Table 2 - Growth and intake of goat kids fed diets with citrus pulp or soybean hulls in partial replacement of corn.

\begin{tabular}{|c|c|c|c|c|c|c|c|c|}
\hline \multirow{2}{*}{ Variables $^{1}$} & \multicolumn{3}{|c|}{-Diets' } & \multirow{2}{*}{ SEM $^{3}$} & \multicolumn{4}{|c|}{ - } \\
\hline & CT & $\mathrm{CP}$ & $\mathrm{SH}$ & & $\mathrm{CT} * \mathrm{COP}$ & $\mathrm{CP} * \mathrm{SH}$ & Per & Diet*Per \\
\hline IBW, kg & 15.9 & 15.8 & 15.6 & 0.73 & 0.50 & 0.72 & - & - \\
\hline MBW, kg & 20.9 & 22.0 & 21.5 & 0.92 & 0.12 & 0.43 & - & - \\
\hline FBW, kg & 24.9 & 27.3 & 26.9 & 1.06 & 0.02 & 0.56 & - & - \\
\hline $\mathrm{ADG}, \mathrm{kg}$ & 0.16 & 0.21 & 0.20 & 0.01 & 0.02 & 0.70 & 0.13 & 0.64 \\
\hline DMI, kg/day & 0.65 & 0.80 & 0.79 & 0.03 & $<0.01$ & 0.73 & $<0.01$ & 0.05 \\
\hline FE, gain:feed & 0.25 & 0.26 & 0.27 & 0.01 & 0.37 & 0.66 & $<0.01$ & 0.30 \\
\hline
\end{tabular}

${ }^{1} \mathrm{IBW}$ : initial body weight; MBW: medium body weight, weight at 28-d of the experimental period; FBW: final body weight, weight at 56-d of the experimental period; ADG: average daily gain; DMI: dry matter intake; FE: feed efficiency (gain:feed).

${ }^{2} \mathrm{CT}$ : Control diet, with $64.2 \%$ corn; CP: citrus pulp diet, replacement of $50 \%$ of corn by CP; SH: Soybean hulls diet, replacement of $50 \%$ of corn by $\mathrm{SH}$.

${ }^{3}$ SEM: Standard error of the mean.

${ }^{4} \mathrm{CT}$ x COP: Control x Coproducts; CP x SH: Citrus pulp x Soybean hulls; Per: Period; Diet x Per: Diet x Period interaction. P $\leq 0.05$.

animals that received the coproducts can be attributed to the adaptation of the animals to the diets, as well as the more favorable rumen environment due to the 90\% of concentrate used (FERREIRA et al., 2011b; GILAVERTE et al., 2011).

The weight of goat kids at the end of the first period (28-d) was not affected by the diets; however, the weight at the end of the second period (56-d) was higher $(\mathrm{P}=0.02)$ for those that received diets containing coproducts compared to the control diet, with no difference between the $\mathrm{CP}$ and $\mathrm{SH}$ diets. The increase in ADG for animals fed diets containing $\mathrm{CP}$ and $\mathrm{SH}$ was not sufficient to alter the weight after 28 days of confinement. However, at the end of the 56 days, it resulted in higher weight, $9.6 \%$ for the diet with $\mathrm{CP}$ and $8.0 \%$ for the diet with $\mathrm{SH}$ in relation to the control diet. There was no difference between diets containing $\mathrm{CP}$ and $\mathrm{SH}$ (Table 2).

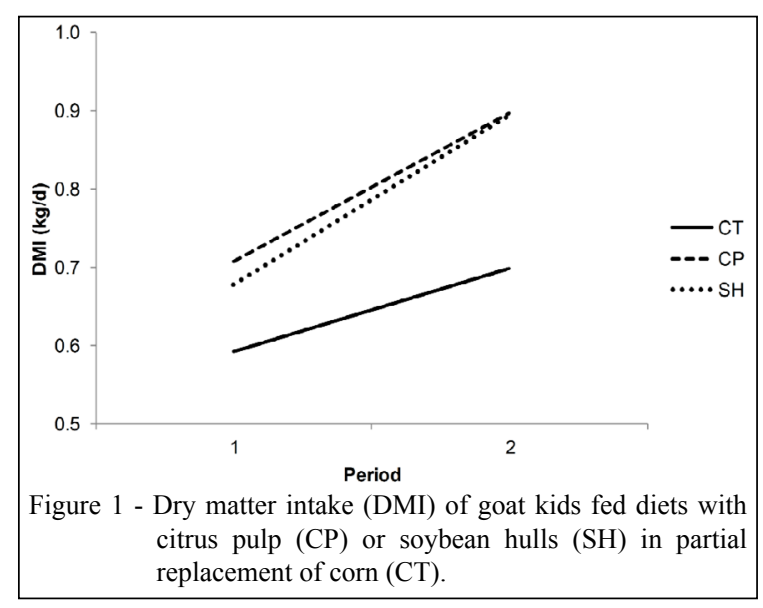

Carcass weights were higher $(\mathrm{P}=0.02)$ for animals fed diets containing the coproducts compared to the control one (Table 3). This response is explained by the higher slaughter weight $(\mathrm{P}=0.03)$ of animals fed diets containing PC and CS. Therefore, the better performance for the animals receiving $\mathrm{CP}$ or $\mathrm{SH}$ resulted in higher carcass gain, especially in relation to the muscular deposition, since differences were observed between treatments $(\mathrm{P}=0.03)$ for LMA (Table 3). RYAN et al. (2007) also reported an increase in carcass weight and LMA as well as thicker subcutaneous fat, when they provided more than 50\% of concentrate in the diet of Boer goats compared to a range diet. In the present study, no difference was observed among diets for SF, HCY, CCY, shrink after chilling and BWT (Table 3). Since the amount of concentrate was the same (90\%) in all diets and half the corn was replaced by $\mathrm{SH}$ or $\mathrm{CP}$, the coproducts caused an increase in weight, but without changing the subcutaneous fat which is likely to be due to the animals being young and goats having a more lean meat deposition. Since the animals used in this experiment were slaughtered young, before puberty, it was expected that animals showing better performance had a positive impact on muscle deposition more than fat deposition. Furthermore, goats have a distinctive feature, with increasing animal physiological maturity there is a decrease in muscle deposition rate while the adipose tissue increases. However, that deposition occurs primarily in the form of visceral fat (PEREIRA FILHO et al., 2005). In addition, FERREIRA et al. (2011a) reported that carcass characteristics of lambs slaughtered at same weight were not affected by the inclusion of $45 \%$ of $\mathrm{SH}$ in high-concentrate diets.

Ciência Rural, v.46, n.4, abr, 2016. 
Table 3 - Carcass characteristics of goat kids fed diets with citrus pulp or soybean hulls in partial replacement of corn.

\begin{tabular}{|c|c|c|c|c|c|c|}
\hline \multirow{2}{*}{ Variables $^{1}$} & \multicolumn{3}{|c|}{ 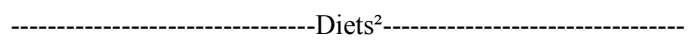 } & \multirow[t]{2}{*}{$\mathrm{SEM}^{3}$} & \multicolumn{2}{|c|}{$--P_{\text {value }}^{4}$} \\
\hline & $\mathrm{CT}$ & $\mathrm{CP}$ & $\mathrm{SH}$ & & $\mathrm{CT}^{*} \mathrm{COP}$ & $\mathrm{CP} * \mathrm{SH}$ \\
\hline $\mathrm{SW}, \mathrm{kg}$ & 26.1 & 28.6 & 27.6 & 0.97 & 0.03 & 0.31 \\
\hline $\mathrm{HCW}, \mathrm{kg}$ & 13.7 & 15.2 & 14.5 & 0.59 & 0.02 & 0.25 \\
\hline $\mathrm{HCY}, \%$ & 52.2 & 52.9 & 52.6 & 0.41 & 0.41 & 0.73 \\
\hline $\mathrm{CCW}, \mathrm{kg}$ & 13.4 & 14.9 & 14.3 & 0.58 & 0.02 & 0.22 \\
\hline $\mathrm{CCY}, \%$ & 51.1 & 52.0 & 51.6 & 0.40 & 0.30 & 0.58 \\
\hline $\mathrm{SaC}, \%$ & 2.02 & 1.60 & 1.87 & 0.12 & 0.06 & 0.11 \\
\hline $\mathrm{SF}, \mathrm{mm}$ & 1.08 & 1.03 & 1.05 & 0.09 & 0.85 & 0.95 \\
\hline BWT, mm & 13.02 & 13.69 & 13.21 & 0.47 & 0.57 & 0.58 \\
\hline LM area, $\mathrm{cm}^{2}$ & 9.63 & 10.33 & 10.64 & 0.28 & 0.03 & 0.46 \\
\hline
\end{tabular}

${ }^{1} \mathrm{SW}$ : slaughter weight; HCW: hot carcass weight; HCY: hot carcass yield; CCW: chilled carcass weight; CCY: chilled carcass yield; SaC: Shrink after chilling; SF: subcutaneous fat; BWT: body wall thickness; LM area: Longissimus muscle area.

${ }^{2} \mathrm{CT}$ : Control diet, with $64.2 \%$ corn; CP: citrus pulp diet, replacement of $50 \%$ of corn by CP; SH: Soybean hulls diet, replacement of $50 \%$ of corn by SH.

${ }^{3}$ SEM: Standard error of the mean.

${ }^{4} \mathrm{CT}$ x COP: Control x Coproducts; CP x SH: citrus pulp x soybean hulls. $\mathrm{P} \leq 0.05$.

\section{CONCLUSION}

Citrus pulp or soybean hulls can replace $50 \%$ of corn in high-concentrate diets $(90 \% \mathrm{DM})$ fed to feedlot goat kids, increasing the average daily gain and dry matter intake enabling higher slaughter weight at earlier age.

\section{ACKNOWLEDGEMENTS}

I. Susin, L.G.M. Gobato and A.P.A. Freire were recipients of scholarships from the Conselho Nacional de Desenvolvimento Científico e Tecnológico (CNPq). D.M. Polizel, R.A. Souza, R.S. Gentil and E.M. Ferreira were recipients of scholarships from Fundação de Amparo à Pesquisa do Estado de São Paulo (FAPESP).

\section{REFERENCES}

ANDERSON, S.J. et al. Digestibility and utilization of mechanically processed soybean hulls by lambs and steers. Journal of Animal Science, v.66, p.2965-2976, 1988 Available from: <http://www.journalofanimalscience.org/ content/66/11/2965.full.pdf + html? sid=eafaf054-58fa-43b2bd8c-1d441989896c >. Accessed: Dec. 14, 2013. doi:10.2134/ jas1988.66112965.

ASSOCIATION OF OFFICIAL ANALYTICAL CHEMISTRY (AOAC). Official methods of analysis. $15^{\text {th }} \mathrm{ed}$. Washington, D.C., 1990. 1298p.

BAMPIDIS, V.A.; ROBINSON, P.H. Citrus by-products as ruminant feed: a review. Animal Feed Science and Technology, v.128, n.3/4, p.175-217, 2006. Available from: <http://dx.doi. org/10.1016/j.anifeedsci.2005.12.002>. Accessed: Dec. 01, 2013. doi: 10.1016/j.anifeedsci.2005.12.002.
BHATTI, S.A.; FIRKINS, J.L. Kinetics of hydration and functional specific gravity of fibrous feed by-products. Journal of Animal Science, v.73, p.1449-1458, 1995. Available from: $<$ http://www.journalofanimalscience.org/content/73/5/1449. abstract? sid=a839fd5b-2e58-4f29-b11f-f97614652496>. Accessed: Oct. 28, 2013. doi:/1995.7351449x.

FERREIRA, E.M. et al. Growth, feed intake, carcass characteristics, and eating behavior of feedlot lambs fed high-concentrate diets containing soybean hulls. Journal of Animal Science, v.89, p.41204126, 2011a. Available from: <http://www.journalofanimalscience. org/content/89/12/4120.abstract?sid=baf8223f-5478-4522-93b1e6ae3fb07f7d > . Accessed: Dec. 05, 2013. doi: 10.2527/jas.2010-3417.

FERREIRA, E.M. et al. Apparent digestibility, nitrogen balance, and ruminal constituents in ram lambs fed highconcentrate diets containing soybean hulls. Journal of Animal Science, v.89, p.4127-4133, 2011b. Available from: <http://www.journalofanimalscience.org/content/89/12/4127. abstract?sid=0f1 ebe0d-b369-4100-9b19-49ba0b91dd8d $>$. Accessed: Oct.12, 2013. doi: 10.2527/jas.2010-3419.

GILAVERTE, S. et al. Diet digestibility, ruminal parameters and performance of Santa Ines sheep fed dried citrus pulp and wet brewer grain. Revista Brasileira de Zootecnia, v.40, n.3, p.639647, 2011. Available from: <http://dx.doi.org/10.1590/S151635982011000300024>. Accessed: Oct. 13, 2013. doi: 10.1590/ S1516-35982011000300024.

HSU, J.T. et al. Evaluation of corn fiber, cottonseed hulls, oat hulls and soybean hulls as roughage sources for ruminants. Journal of Animal Science, v.65, p.244-255, 1987. Available from: <http://www.journalofanimalscience.org/content/65/1/244. full.pdf + html? sid=72bd3ebe-aaaf-49d6-8757-1a33b38203b1 >. Accessed: Oct. 14, 2013. doi:10.2134/jas1987.651244x.

IPHARRAGUERRE, I.R.; CLARK, J.H. Soyhulls as an alternative feed for lactating dairy cows: a review. Journal of Dairy Science, v.86, n.4, p.1052-2073, 2003. Available from: <http:// www.journalofdairyscience.org/article/S0022-0302(03)73689- 
3/abstract $>$. Accessed: Oct. 20, 2013. doi: 10.3168/jds.S00220302(03)73689-3.

MERTENS, D.R. Creating a system for meeting the fiber requirements of dairy cows. Journal of Dairy Science, v.80, n.7, p.1463-1481, 1997. Available from: <http://www.journalofdairyscience.org/ article/S0022-0302(97)76075-2/abstract $>$. Accessed: Sept.11, 2013. doi: $10.3168 /$ jds.S0022-0302(97)76075-2.

MULLIGAN, F.P. et al. The effect of feeding level on the retention time and degradability of soya hulls. In: AGRICULTURAL RESEARCH FORUM, 1999, Dublin. Proceedings... Dublin: Faculty of Agriculture, 1999. p.135-136.

NATIONAL RESEARCH COUNCIL. Nutrient requirements of small ruminants: sheep, goats, cervids and new world camelids. Washington: National Academies, 2007. 362p.

NOTTER, D.R. et al. Growth and carcass characteristics of lambs sired by Dorper and Dorset rams. Journal of Animal Science, v.82, n.5, p.1323-1328, 2004. Available from: $<$ http://www.journalofanimalscience.org/content/82/5/1323. abstract? sid=34ccd861-77d8-4fa 1-9cdc-bf415013fe $8 \mathrm{f}>$. Accessed: Dec. 14, 2013. doi:/2004.8251323x.

PEREIRA FILHO, J.M et al. Effect of feed restriction on economical and productive performances of F1-Boer x Saanen goats. Revista Brasileira de Zootecnia, v.34, n.1, p.188196, 2005. Available from: <http://www.scielo.br/scielo. php?script=sci_arttext\&pid=S1516-35982005000100023\&lng $=$ en $\&$ nrm=iso $>$ Accessed: Apr. 01, 2015. doi 10.1590/S151635982005000100023 .

RYAN, S.M. et al. Effects of concentrate level on carcass traits of Boer crossbred goats. Small Ruminant Research, v.73, p.677, 2007. Available from: <http://www.sciencedirect.com/science/ article/pii/S0921448806003403>. Accessed: May 05, 2014. doi: 10.1016/j.smallrumres.2006.11.004.

SAS INSTITUTE. SAS User's guide: Statistics. Version 9.2. Cary, NC., 2008. 473p.

VAN SOEST, P.J. et al. Methods for dietary fiber, neutral detergent fiber, and nonstarch polysaccharides in relation to animal nutrition. Journal of Dairy Science, v.74, p.3583-3596, 1991. Available from: <http://dx.doi.org/10.3168/jds.S00220302(91)78551>. Accessed: Nov. 14, 2013. doi: 10.3168/jds. S0022-0302(91)78551-2.

WING, J.M. et al. Effects of citrus molasses, distiller solubles and molasses on rumen parameters and lactation. Journal of Dairy Science, v.71, n.2, p.414-420, 1988. Available from: <http:// dx.doi.org/10.3168/jds.S0022-0302(88)795715>. Accessed: Oct. 28, 2013. doi:10.3168/jds.S0022-0302(88)79571-5. 